\title{
JUSTIFICATION OF, AND BENEFITS REALIZATION BEYOND IT INVESTMENTS: ANALYSIS FROM LITERATURE
}

\author{
Godfred Yaw Koi-Akrofi \\ Department of IT Studies, University of Professional Studies, Accra
}

\begin{abstract}
This work looked at the justification of IT investments in general, to draw important conclusions that could be beneficial to IT project managers and professionals, and then zero in on the angle of benefits realization beyond IT investments.About 30 categories/sets of research outputs or articles out of more than 60 articles reviewed were used for this work. No primary data was employed for this work. Articles were sourced from databases such as Google Scholar, Research Gate, Academia.edu, Google search engine, Elsevier, and so on. The main themes used for the search were IT investments, Justification for IT investments, IT investments benefit determination, value creation beyond IT investments, and so on. The results showed that justification is unique to every firm, it is contextual, and so stakeholders must take into consideration environmental factors, corporate and strategic goals, experience and expertise of stakeholders, and so on, to design its framework and measures to justify IT investments. Zeroing on benefits realization, two things run through all the discussions: benefits realization of IT investments must take into consideration the organization's strategic objectives and that they do not simply emerge, as if by magic. Their realization has to be planned, delivered, reviewed, and exploited to ensure value realization on a more consistent/constant basis.
\end{abstract}

\section{KEYWORDS}

Information technology, benefits realization, investments, strategic, justify

\section{INTRODUCTION}

Information Technology (IT) investments are inevitable in today's world of business since IT plays a key or pivotal role in the set-up of all forms of businesses to ensure productivity and efficiency [1]. Businesses, therefore, invest a huge amount of money in IT in the bid to ensure the benefits. Due to budgetary constraints, IT investments compete with all other overheads of businesses, and hence IT investments must be justified with clear benefits intended to accrue to the business in the short to long term before they are approved to be done. Justification of IT investments has so many dimensions. This work looks at the justification of IT investments in general, draws important conclusions that could be beneficial to IT project managers and professionals, and then zero in on the angle of benefits realization beyond IT investments.

This work, therefore, intends to look at the various arguments from literature that can be put forward to justify IT investments in organizations. It is also intended to contribute to the general body of knowledge and research work in the IT project management space, specifically, in the area of justification of IT investments.

\section{Materials AND MethodS}

A detailed extant literature review is conducted relating to IT investment justification and benefits realization. This work only deals with secondary data, primarily from journal articles. 
About 30 categories/sets of research outputs or articles out of more than 60 articles reviewed are used for this work. No primary data is employed for this work. Articles were sourced from databases such as Google Scholar, Research Gate, Academia.edu, Google search engine, Elsevier, and so on. The main themes used for the search are IT investments, Justification for IT investments, IT investments benefit determination, value creation beyond IT investments, and so on. Some of the limitations encountered with this methodology are the difficulty in getting the most current articles on the subject matter from databases, and also the fact that some databases cannot be accessed until payment is made. This is worrying as it can affect the results of the research.

\section{RESUltS}

\subsection{Introduction}

The literature for this research work is sourced from several thematic areas based on the conceptual framework employed. The conceptual framework which also has its basis from the framework of Koi-Akrofi, G. and Koi-Akrofi, J. [2] is shown in Figure 1 below:

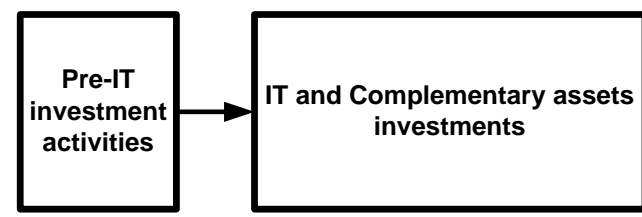

Tangible and Intangible values/benefits/ gains created beyond IT and

Complementary assets investments

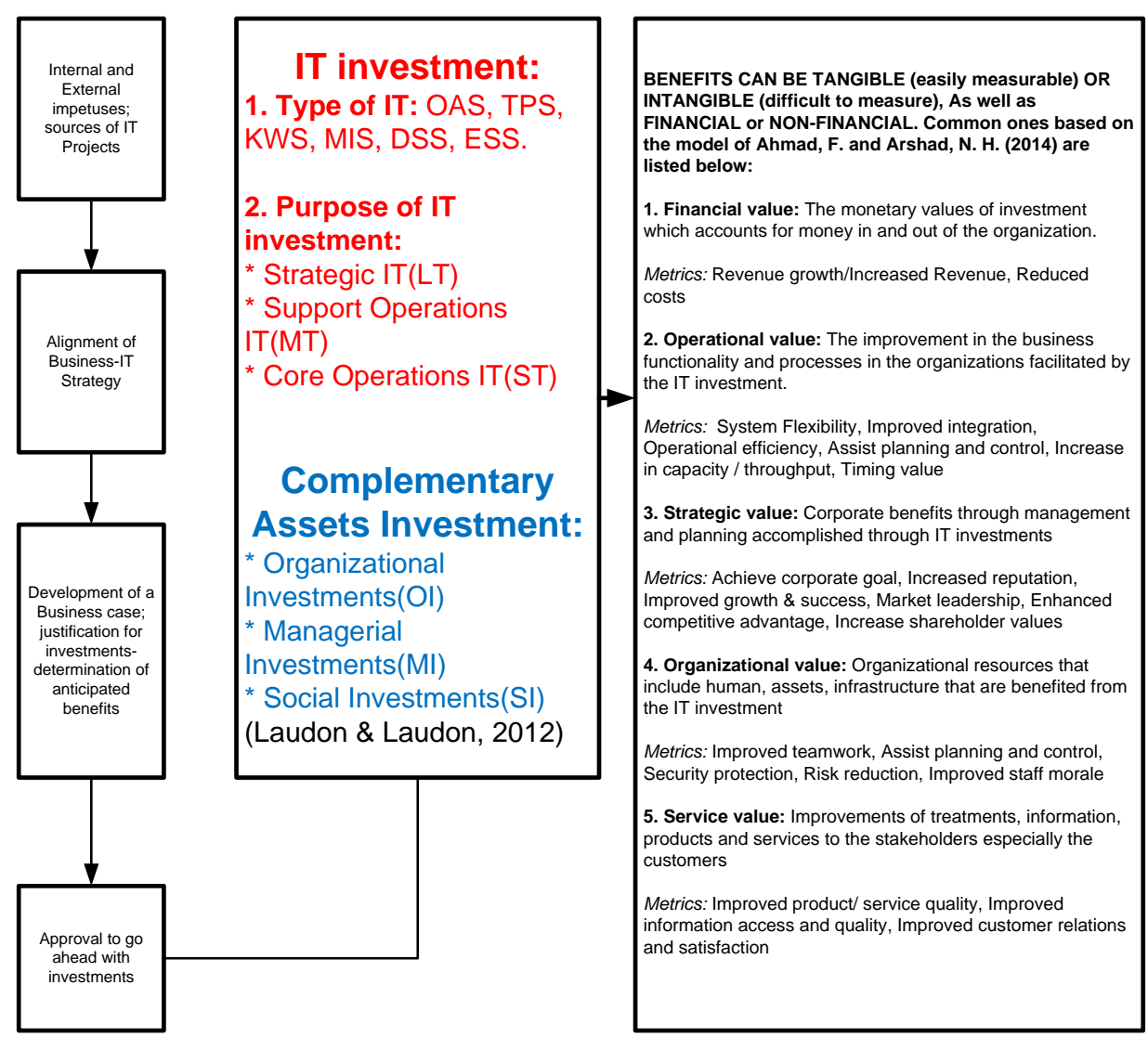

Figure 1: Conceptual Framework 
Source: Author

Based on the framework above, the thematic areas that literature is sourced and reviewed are as follows:

- The sources/derivatives of IT investments in organizations

- Alignment of business and IT strategies in organizations

- Benefits realization beyond IT investments

This is done by taking into consideration the theoretical, empirical, and methodological aspects of the literature.

\subsection{The Sources of IT Investments in Organizations}

IT investments/projects in organizations are driven by several factors. Generally, these factors fall under two broad categories: Internal and External factors.

\subsubsection{Internal Factors}

Internal factors are all impetuses derived from inside of the organization. This may include strategic reasons (Top-down) and operational reasons (bottom-up).

The strategic impetus is preceded by the question "why the need for IT investments?" This question is typically asked and answered by management, speaking to a top-down stimulus that most of the time is fueled by the passion or strong desire and need towards increasing the upper hand over competitors through IT [2].

Operationally, employees on the other hand, through reports, departmental gatherings/meetings, and sorted out discussions, do push for IT investments/projects which may not be deliberately arranged (strategic), but rather are fueled from bona fide concerns relating to their work. This is by and large known as base up or bottom-up approach/ catalyst, which in most cases is meant to address operational concerns [2]. Operational concerns may include the need to replace inefficient systems, outdated systems, systems that vendors no longer support, etc.

\subsubsection{External Factors}

External factors are impetuses derived from outside the organization, and yet have a significant impact on the organization in terms of competitive advantage, revenues, customer satisfaction, etc. External factors may include customer impetuses, vendor/supplier impetuses, and competition.

In this era of IT, customers are extremely complex and will preferably patronize an organization's products and services if it shows modernity regarding IT. In this regard, customers' IT demands form an integral part of the items for decisions on IT investments [2]. These concerns can well be captured from reports showing feedbacks from customers.

Sellers (vendors) and providers (suppliers) in their quest to make more profits and remain in business, consistently come out with new levels of IT hardware advancements or improvements and programming patches, redesigns, and upgrades which they inevitably compel on the organizations they are providing. The management of these organizations is, therefore, in most cases, forced to make impromptu IT investments. The Sellers (vendors) and providers (suppliers) 
do it in a manner that there is little that these organizations can do to oppose or resist. One of the ways they use to accomplish this is to pronounce that they don't offer help and extra parts for the old IT hardware [2]. The organizations may not be ready for these software patches, redesigns, and upgrades, but for the fear that they would be left behind in the industry they are operating, which in the long run may have dire consequences on their operations and revenues, they are forced to consider them.

Competition is also one of the external impetuses that influence the decision by management to invest in IT. To keep pace with competition and be relevant in an industry, one must be abreast with the technological changes in the industry and respond appropriately. Failure to do that may result in undesirable conditions for the entity such as the decline in customer base/market share, the decline in revenues, etc. IT innovations change at a fast pace, and the management of entities would have to respond with IT investments/projects to stay relevant in this era of IT.

Figure 2 below shows the IT project/Investment derivative in Industry.

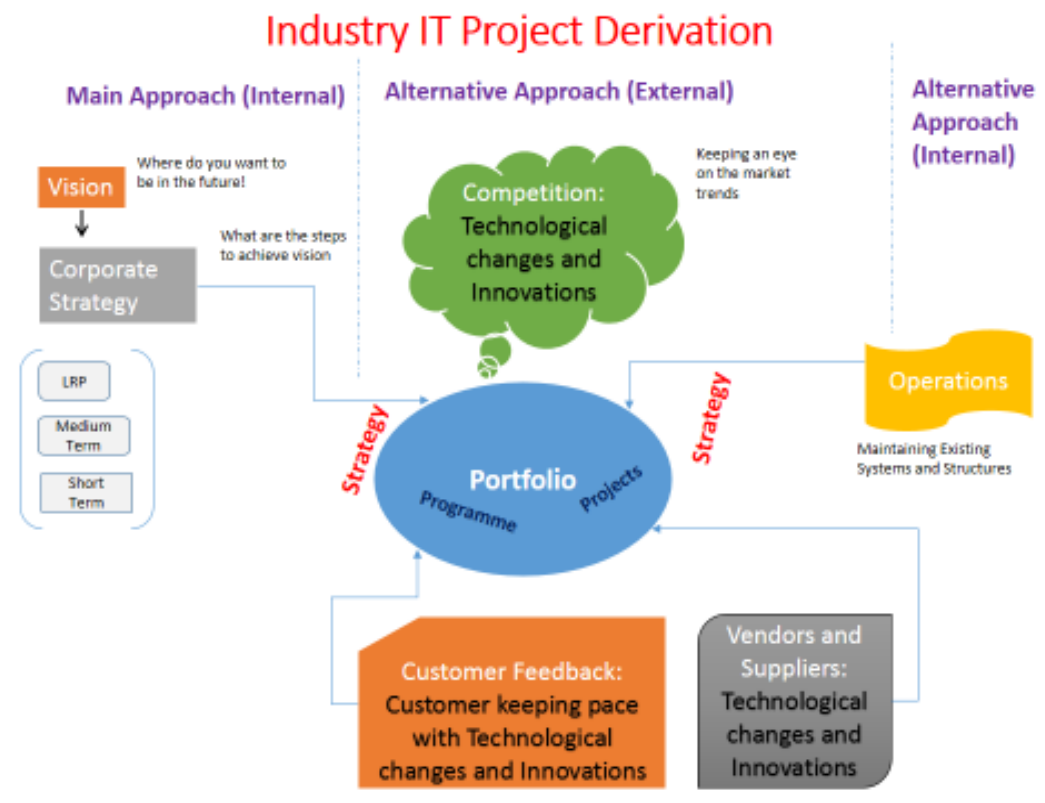

Figure 2: IT project/Investment derivative in Industry

Source: Author

\subsection{Alignment of Business and IT Strategies in Organizations}

Issa-Salwe and Aloufi [3] characterize an IT Strategy as an arrangement or plan to embrace IT as per organizational requests/demands to bolster the overall business strategy. Peppard and Ward [4] also indicated that an IT Strategy aids to determine the organization's capabilities and addresses the question of how it can support the business goals and objectives (as cited in Kekwaletswe, R. M., \& Mathebula, P. C. [5]). On the other hand, Zahra and Covin [6] characterize business strategy as the long haul plan an organization defines to accomplish a desired future for the business. It includes building up the purpose and scope of the organization's undertakings, considering the way of the business it is in and the environment in which the entity works, and their competition and client requests and demands. This is reinforced by Silvius [7] who includes that business strategy is the foundation of the business' long haul 
goals and objectives and the appropriation of actions and apportionment of resources important for meeting those objectives to prevail in its market against rivalry/competition.

IT investments are a key component of IT strategy in organizations. Alignment between an organization's business strategy and its information systems strategy positively affects business performance [8]. IT strategy is meant to give the organization a competitive advantage over its competitors in the industry. An IT strategy is a fundamental part of the overall organizational strategy. It is an exhaustive arrangement that aids institutions in how innovation/technology can help them accomplish their objectives, support their aggressiveness, and increment their odds of progress through technological innovation, cost savings, and process mechanization [9]. This presupposes that IT investments are an essential component of business strategy.

The IT strategy ought to consider all features of technology management, including cost control, aptitudes/skills, hardware, software, risk management, and other areas of big business IT, and also how investments in these abilities bolster the general business strategy [9].

IT investments give the IT infrastructural base for the organization, but caution must be given here that, not all IT investments are necessary for the business to achieve its goals, and also help it maintain its competitiveness; this is the more reason why IT investments, which is an essential part of the IT strategy, must be aligned to the business strategy.

\subsubsection{What is Alignment?}

There are several definitions for alignment in literature, but a few relevant ones are considered here. Simplistically, Luftman, Papp, and Brier [10] define the concept of alignment as doing the right things, i.e. effectiveness, and doing things right, i.e. efficiency. This definition is a general one devoid of technicalities, but later on, Luftman [11] in giving a practical dimension to it defined alignment by stating that it refers to using IT in a way that is fitting to support business needs, strategies and objectives.

Osborn [12] defines aligning IT with the business as creating and managing a business-driven IT organization for which the primary focus is implementing information-oriented solutions that are most important to meeting the business goals, objectives, and strategies of the enterprise. Sue and Perez [13] also indicate that alignment exists when:

i. IT capabilities

- $\quad$ support the business capabilities that are needed to execute the business strategy

- have the flexibility to accommodate business strategy changes

ii. IT investments are justified by the business based on benefits from the business transformations that they enable

iii. The directional aspects (principles, policies, standards, and architectures) of IT strategy are driven by the business strategy

Henderson and Venkatraman [14] also describe alignment as the degree of fit and amalgamation among business and strategy and then business and IT infrastructure; but Chan, Sabherwal and Thatcher [15] simply describe alignment as the fit between business and IT strategic orientation, which is a slight departure from the definition of Henderson and Venkatraman [14]. Alignment is the extent to which the IT goals and objectives aid and are aided by the business goals and 
objectives [16]. This is a practical definition that was supported by Gartlan and Shanks [17] who also state that alignment of business and IS strategies comprises the process of framing both the business and IT strategies that are complementary to each other and also interconnected.

\subsubsection{Why IT must align with Business Strategy?}

Osborn [12] gave the following reasons why alignment is an issue in organizations:

- IT organizations do not have a clear understanding of what is important to the business.

- The value of IT is not understood by business executives (and some IT executives).

- Opportunities to use information technology are not identified, authorized, prioritized, and implemented, based on importance to meeting business objectives and goals

- The business does not participate, from an enterprise-wide perspective, in decisions regarding IT direction and priorities.

The above reasons are enough consideration for the alignment of IT strategy and business strategy.

Beveridge [18] on the other hand, by emplaning why IT has become a key business function in almost every organization, reiterated the expectations of organizations of future benefits of IT investments and went ahead to enumerate 9 reasons why IT must align with Business strategy: To

- Reduce costs.

- Standardize processes.

- Enhance productivity.

- Improve workflow and communications.

- Sustain repeatable service levels.

- Improve Risk control mechanisms.

- Implement new business strategies.

- Facilitate organic and acquisition-driven growth.

- Gain a competitive advantage by exploiting new technology.

Adding their bit to the subject matter of why the need for alignment, Sue and Perez [13] also enumerated three reasons. They maintained that it is:

- Because failed IT investments come straight off the bottom line, without adding anything back.

- Because of lost opportunities to improve business positioning

- Because it can result in a major setback for the organization in terms of the capabilities it needs to compete.

- From literature, the following are some of the benefits of alignment:

- IT alignment is connected to performance or results in improved performance [19-23]

- Alignment is critical because it helps organizations in making sure that the areas which are required for enhanced organizational performance are targeted by information systems [24, 25].

- Alignment improves the comprehension of business management about the significance of IT and in the meantime enhancing the comprehension of business objectives and targets by IT supervisors [26].

- Alignment maximizes the return on investment for IT [22, 27].

- Alignment enhances competitive advantage $[22,28]$. 
- Alignment guarantees that the IT unit bolsters the objectives and goals of the organization to get business value from IS [19, 28, 29].

- Critical applications needed for growth are identified when alignment is done [30].

- Alignment guarantees that IT planning and business planning activities are in a state of harmony keeping in mind the end goal to guarantee smooth amalgamation so that organizational goals and objectives can be accomplished [28].

- Alignment ensures successful IT and business unit operations [19].

- Alignment is an enabler/facilitator for innovation in an organization [22, 31].

\subsubsection{What is Necessary to Align IT with the Business?}

There are some key/critical points or areas to consider when aligning IT with the business. These areas when considered will make the alignment effective and will achieve the expected results. Osborn [12] enumerated 5 areas worth considering in this write-up. They are as follows:

- Assuring that all IT activities contribute to the goals, objectives, and strategies of the business.

- Encouraging Executive Business Management to become continuously involved in plans and decisions regarding the use of information technology.

- Positioning the IT organization to best address the needs of the business

- Creating a customer-focused culture in the IT organization

- Enhancing the awareness of the value of IT to the business

- The fifth point "Enhancing the awareness of the value of IT to the business" is very key as is one of the problematic areas when it comes to IT investments in organizations. Managers tend to have little knowledge about the value created by IT investments [12], and hence do oppose in most cases, investments in IT. To achieve the above, Osborn [12], again came out with a 5-point requirement. They are as follows:

- Educating management concerning the significance of partnering with the IT organization

- Relinquishing some control to the business concerning decisions about information technology (strategy, architecture, priorities, spending, etc.)

- Making IT-related decisions with the same benchmarks used by the business

- Aligning the IT Organization structure, style, staffing, and skills to match the requirements of the business

- Creating a process that keeps the business and IT aligned

\subsection{Justification of IT Investments and Benefits Realization Beyond IT Investments}

Research [32] has shown that IT investment benefits can be grouped into two key categories: tangible and intangible. From the beginning, intangible benefits are almost impossible to define and once found, difficult to measure/quantify and difficult to justify/evaluate for that matter. Tangible benefits are insufficient to legitimize IT investments because they often point to shortterm corporate gains, and intangible gains rationale or justification must be included to ensure that the rationale or justification process is complete irrespective of how controversial or problematic it may be. Intangible benefits also are usually strategic, necessitating some time for benefits to be realized, which must be seen as such; and so, managers should therefore not rush to get immediate results.

Again, from literature [32], it was also realized that no appraisal framework/model with its associated methods of appraisal is a cure-all to the evaluation problem; evaluation is contingent on so many factors, and so is contextual or circumstantial. It depends on environmental factors 
such as the size of the firm, the type of IT investment, the industry the firm is operating in, the expertise of the stakeholders involved, the experience of key stakeholders involved, and so on. Figure 3 below, therefore, is a model (Contextually Specific IT Investment Justification ModelCSIIJM) developed to depict the contextual nature of IT investment justification.

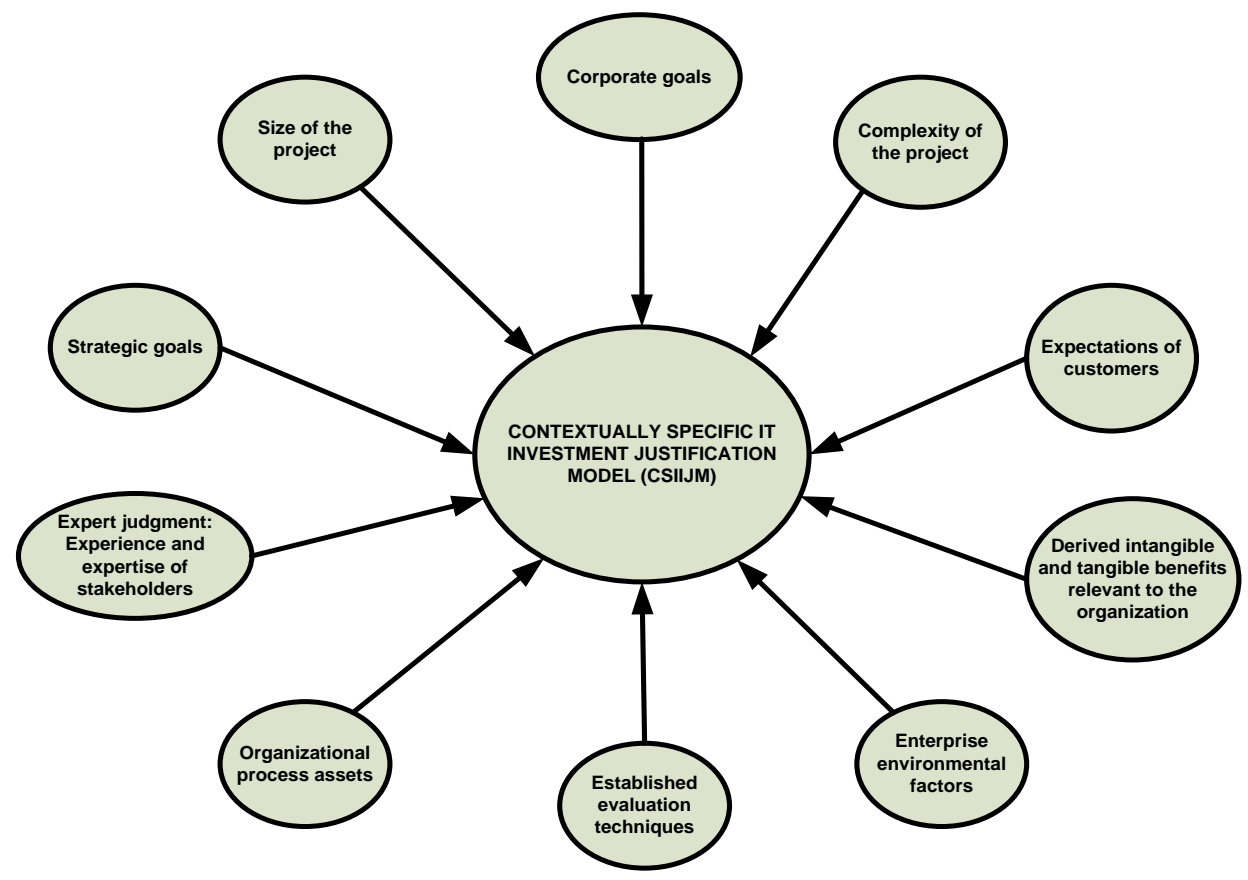

Figure 3: Contextually Specific IT Investment Justification Model (CSIIJM)

Source: Author

From Figure 3, we argue that IT investment justification is contextually specific to an organization, and depends on the following:

1. Organization's strategic goals

2. Organization's corporate goals

3. Expert judgment: Experience and expertise of stakeholders

4. Organizational process assets: Standardized guidelines, Proposal evaluation criteria, Work breakdown structure templates, Project schedule network diagram templates, Risk templates, Organizational standard processes, Project closure guidelines, Defect management processes, Lessons learned and historical databases, Change control procedures, Financial control procedures, project files.

5. Established evaluation techniques

6. Enterprise environmental factors: Organizational culture, processes, and infrastructure, Product standards, Quality standards, Government standards, Market standards and conditions, Codes of conduct, Staffing guidelines, Reviews, and training records, Work authorization systems, Political unrest, Organizational communication channels, Risk databases, Project management information systems (PMIS) - Automation tools like schedule tool

7. Derived tangible and intangible benefits relevant to the organization

8. Expectations of customers

9. The complexity of the project

10. Size of the project 
Each firm should be able to incorporate data, evaluation techniques, personal experience, personal knowledge, corporate or departmental politics, personal desires, and intuition in its evaluation process, for the fact that these are a range of input information required for the IT evaluating process. This promotes the uniqueness of each firm in terms of the process/framework/model.

Allowing some benefits during the decision-making process, even though it may not have immediate direct tangible positive outcomes, to overcome the financial considerations, is key for the long-term financial success of the firm sometimes. A typical example is customer satisfaction, where the benefits may not be realized immediately, but in the long run, it may result in huge financial gains for the firm due to the possibility of an increased number of customers and more revenue.

Factoring into the process of IT evaluation, corporate and strategic objectives of the firm is key. To have in-depth knowledge of the strategic and corporate objectives of the firm will go a long way to help stakeholders understand the types of tangible and intangible benefits that should be expected, and this will help the evaluation process immensely.

We have reached a stage in operations worldwide where IT investments are a "must do" for every firm. In as much as justification is key to determine the kinds of IT projects to undertake and which not to undertake, or to prioritize a list of projects in a portfolio, some IT projects must be done without any justification performed. Such projects are done to stay in the competition, and to remain relevant in the industry, as well as make your customers loyal and happy all the time. Customers will automatically sway to where there are technology and innovation; especially in cases where a customer can port to another company like in the Telecom sector. This means that even though you may not be able to justify the investment, you are bound to do it if you want to stay in business and still have customers to serve.

Schubert and Williams [33] in identifying and understanding enterprise system benefits developed a four-level framework of a thorough classification of prospects and benefits: Business design (strategy and processes), Management (Resources), Functional areas (functions), Information Technology and infrastructure (technology components). The business design has to do with benefits regarding the improvements in the strategic objectives and the processes (processes and workflows). Management has to do with benefits impacting the levels of employees, product design, and cost aspects (finance). Functional areas focus on the modules and functions of enterprise resource planning (ERP) systems, and Information Technology and infrastructure, an often-realized benefit, is the integration of various databases and thus achieving or realizing a uniform view of enterprise data.

In achieving and maximizing the benefits of IT performance management, that is, focusing on IT performance management as an essential action to take care of the removal of non-value adding activities and processes, Drost, Harmsen, Brinkkemper, and Versendaal [34] posit that benefits of IT performance management is that a focus on the realization of strategic, financial and nonfinancial goals is applied and that KPIs are made explicit and measurable. IT performance management calls for effective IT management to meet business objectives. The IT performance measurement process should be chosen. Performance measurement frameworks should be adjusted, multidimensional, complete, and coordinated into the organizational performance frameworks. Performance measurement frameworks incorporate measurements/metrics and a planning/budgeting approach. Performance metrics are utilized to regulate measures and need to coordinate the objectives of the association. 
Radhakrishnan, $\mathrm{Zu}$, and Grover [35] examined the relationship between IT and business value from a process-oriented perspective and helped to identify the underlying or fundamental links between IT and its differential business value to firms. The process framework they developed explains the fact that IT impacts both management and operational processes, and these produce capabilities known as Management Process Capabilities (MPC) and Operational Process Capabilities (OPC) to produce firm performance. They also revealed that effective deployment of IT can improve firm-level financial metrics reflecting operational and management processes, thereby creating differential advantage when compared or matched to their industry counterparts. They continued to say that what matters is how to use IT effectively or meritoriously on key organizational processes to create differential business value to firms.

In assessing the benefits of business intelligence systems, Hočevar and Jaklič[36] concluded that, in addition to calculable/quantifiable and indirectly calculable/quantifiable benefits, it also brings certain benefits which are difficult to measure or even unmeasurable, as well as some unpredictable benefits which are revealed only after a certain period of use of business intelligence. They kept explaining that IT investments should be aligned with the organization's strategic objectives. This means, on the one hand, investments in modern and efficient information technology should be an integral/essential part of the strategy of the company, and, on the other hand, information technology should help the company achieve its strategic goals/objectives. They concluded by saying that the benefits of business intelligence (increased sales/revenue, increased income/profits, improved customer satisfaction, cost reduction, increased market share, improved user satisfaction and motivation, and faster decision-making) can be related successfully to the established long-term business strategy. The investment, therefore, helps the company achieve its strategic objectives which are, according to Carver and Ritacco [37] (p. 19), one of the crucial criteria for deciding whether the investment in business intelligence is justified or not.

Ashurst, Doherty, and Peppard [38] came out with four distinct competencies which should enhance an organization's ability to realize value from their IT investments, on a more consistent/constant basis: Benefits planning- 'the ability to effectively identify and enumerate the planned outcomes of an IS development project and explicitly stipulate how they will be achieved'. Benefits do not simply emerge, as if by magic, from the introduction of new technology. Their realization needs to be carefully planned and managed [39, 40]; Benefits delivery- 'the ability to design and execute the program of organizational change necessary to realize all of the benefits specified in the benefits realization plan'. Benefits principally arise from the organizational change that accompanies an IT implementation, rather than directly from the technology [41, 42]; Benefits review- 'the organization's ability to effectively assess the success of a project in terms of the potential benefits, the delivered benefits, and the identification of the ways and means by which further benefits might be realized.' Benefits review is therefore considered as being an ideal occasion for organizational learning [43], to ensure that its capacity to successfully realize benefits from IT projects, can over some time be enhanced or improved. Benefits exploitation- 'the adoption of the portfolio of practices required to realize the potential benefits from information, applications, and IT services, over their operational life'. Ward and Daniel [43] argue that the quest to leverage benefits from a piece of business software should not cease as soon as it has been implemented.

Mithas, Ramasubbu, and Sambamurthy [44] also revealed that Customer Focused Results, Financial Results, Human Resource Results, and Organizational Effectiveness Results are deemed to be achieved by Information Management Capability through Performance Management Capability, Customer Management Capability, and Process Management Capability as mediating factors. They continued to say that senior leaders must focus on creating the 
conditions necessary to develop IT infrastructure and information management capabilities because they play a fundamental role in building other capabilities for improving firm performance. ICT positively affects efficiency measures and a negative impact on productivity measures, showing that ICT typically turns out to be an auxiliary need for firms to stay aware of their rivals. Market measures can capture the present and future advantages/benefits of the technologies, especially the elusive/intangible advantages/benefits, for example, increments in the company's adaptability and upgrades in item and process quality, which are not captured directly in the conventional ratios.

Market measures also take account of the effects stemming from the existence of complementarities between ICT and the rest of the firm's resources and capabilities [45]. In their analysis of Volvo IT, Sakar and Widestadh [46] concluded that Volvo IT, like many other organizations, focussed on conventional IS / IT investment measures, namely cost, productivity, and time, rather than the business change brought about by the IS / IT investment and that learning from the results is significant. This learning, especially after several projects have been evaluated, may lead to noteworthy improvements in subsequent evaluation projects. The relationship between IT capabilities and firm Performance is more complex or difficult than scholars have put forward [47]. Firm performance is seen to be a result of Internally focused IT capabilities and Externally focused IT capabilities with mediating factors as environmental conditions [47].

The framework developed by Karlsson and Stypsanelli [48] has considerations as strategic, tactical, operational, and financial. These considerations have strategic (competitive advantage, alignment, customer relations), informational (information access, information quality, information flexibility), and transactional (communications efficiency, Systems development efficiency, business efficiency) benefits, which determine the justification of investments in IT projects. They argued that several benefits are considered during the investment decision-making process and that these benefits are important to the final decision and overcome certain financial constraints; out of these benefits, customer relations and business efficiency are those that most influence the decision-making process.

Schryen [49] is, however, of the view that the relationship/correlation between IS investment and productivity varies widely between companies and that the incorrect measurement of IS investment impact can be rooted in delayed effects. The alignment of an organization's business strategy with its information system strategy has a positive impact on business performance [8]. IT-enabled organizational transformational benefits were found to exist as a distinct benefit category and to be closely related to other forms of IT-generated business benefits [50].

Ahmad and Arshad [51] in their value delivery of IT framework stated 5 categories of values that are key and quite exhaustive. The 5 categories of values are Operational value- The improvement in the business functionality and processes in the organizations facilitated by the IT investment. Some of the measures of operational value are System flexibility, Improve integration, Operational efficiency, Assist planning \& control, Increase in capacity/throughput, Timing value; Financial value- The monetary value of an investment which accounts for money in and out of the organization. Some of the measures are Revenue growth, Reduced costs; Strategic valueCorporate benefits through management, and planning accomplished through IT investments. Some of the measures are Achieve corporate goals, Increase reputation, Improved growth \& success, Market leadership, Enhanced competitive advantage, Increase shareholder values; Organizational value- Organizational resources that include humans, assets, infrastructure that are benefited from the IT investment. Some of the measures are Improved teamwork, Assist planning and control, Security protection, Risk reduction, Improved staff morale; and Service value- 
Improvements of treatments, information, products, and services to the stakeholders, especially the customers. Some of the measures are improve product/ service quality, improve information access and quality, improve customer relations and satisfaction.

Generally, for tangible and measurable profitability benefits, the measures are Return on Assets (ROA), Return on investment (ROI), Return on Equity (ROE), Net Profit (NP), Net Profit Margin (NPM), Earnings Before Interest and Taxes (EBIT), The researchers for this area include Hitt and Brynjolfsson [52], Sircar et al. [53], Beccalli [54], Stratopoulos and Dehning [55]. For tangible productivity benefits, some of the measures are ratio and non-ratio Cobb Douglas's productivity models, and researchers include Brynjolfsson, E. [56], Brynjolfsson and Hitt [57], Brynjolfsson and Hitt [58], Brynjolfsson and Hitt [59]. Tangible market benefits have measures such as Tobin's q, market share, etc., and researchers include Bharadwaj and Konsynsky [60] and Richardson et al. [61].

Tangible and intangible intermediate results have measures such as Innovation, improvement in decision-making, inventory turnover, capacity utilization, quality, new product introduction, etc., and researchers include Davenport [62], Hammer and Champy [63], and Barua et al., [64]. Consumer welfare (tangible and intangible benefits) mainly covers value created for customers by IT investments by the organization, and researchers include Bresnahan [65], Brynjolfsson [66], and Brynjolfsson [67]. Intangible benefits are industry dependent. For example, for the health sector, IT investments can result in intangible benefits like improved customer service, reduced wait times, increased public safety, decreased operational errors, and attention to public health issues [68].

\section{CONClusion}

From the literature review, the way forward for IT investments justification is that justification is unique to every firm, it is contextual, and so stakeholders must take into consideration environmental factors, corporate and strategic goals, experience and expertise of stakeholders, and so on, to design its framework and measures to justify IT investments. A model, known as Contextually Specific IT Investment Justification Model (CSIIJM), is therefore developed to support this view (See Figure 3)

Again, zeroing on benefits realization, from the literature reviewed so far, two things run through all the discussions or stand out. These are:

i. Benefits realization of IT investments must take into consideration the organization's strategic objectives. This means, on the one hand, investments in modern and efficient information technology should be an integral/essential part of the strategy of the company (IT and business strategies alignment), and, on the other hand, information technology should help the company achieve its strategic goals/objectives (competitive advantage, excellent customer relations, and so on)

ii. Benefits realization of IT investments does not simply emerge, as if by magic. Their realization has to be planned, delivered, reviewed, and exploited to ensure value realization on a more consistent/constant basis.

\section{REFERENCES}

[1] Lin Ã, B-W. Information technology capability and value creation: Evidence from the US banking industry. Technology in Society, ScienceDirect, Elsevier. 2007, 29, 93-106. 
[2] Koi-Akrofi, G.Y.; Koi-Akrofi, J. Information Technology investments and organizational performance of the telecommunications industry in Ghana. Maxwell Scientific Organization. Research Journal of Information Technology. 2011, 3(3): 118-132.

[3] Issa-salwe, A.; Aloufi, K. Integrating Competitive Advantage with Strategic Information Systems Planning: A Review. 8(1), 2011 Published by Academy of Taiwan Information Systems Research. National Pingtung Institute of Commerce. 2011.

[4] Peppard, J.; Ward, J. Strategic planning for information systems. West Sussex, England: John Wiley \& Sons. 2002.

[5] Kekwaletswe, R.M.; Mathebula, P. C. Aligning Information Systems Strategy with the Business Strategy in a South African Banking Environment. 2014 proceedings of the conference for Information System Applied Research Baltimore, Maryland USA. 2014, ISSN: 2167-1508 v7 n3321.

[6] Zahra, S.; Covin, G. Business strategy, technology policy and firm performance. Strategic Management Journal. Wiley Online Library. 1993.

[7] Silvius, A. Aligning IT strategy to business strategy in a multi business company. America's Conference on Information Systems (AMCIS), Denver. 2007.

[8] Nikoloski, K. The Role of Information Technology in the Business Sector. International Journal of Science and Research (IJSR). 2014, Volume 3 Issue 12, PP. 303-309

[9] Riordan, D. Top 5 steps to define an effective IT strategy. 2015, Retrieved on 23/02/2017 from http://www.itnewsafrica.com/2015/03/top-5-steps-to-define-an-effective-it-strategy/

[10] Luftman, J.; Papp, R.; Brier, T. Enablers and Inhibitors of Business-IT Alignment. Communications of the Association for Information Systems. 1999, 1(11), $1-33$.

[11] Luftman, J. Key issues for IT Executives 2004. MIS quarterly executive. 2005, 4(2), 269-285.

[12] Osborn, P. Aligning Information Technology with the business. Society for Information Management.n.d,

[13] Sue, P.; Perez, A. IT Strategy and Business Strategy: Business Strategy: A Path to Alignment. Chartwell Inc. 2006.

[14] Henderson, J.; Venkatraman, N. Strategic alignment: Leveraging information technology for transforming organizations. IBM Systems Journal. 1993, 32(1), 472-484.

[15] Chan, Y.; Sabherwal, R.; Thatcher, J. Antecedents and outcomes of strategic IS alignment: An empirical investigation. IEEE Transactions on Engineering Management Journal. 2006, 53(1), 27-47.

[16] Reich, B.; Benbasat, I. Factors that influence the social dimension of alignment between business and information technology objectives. MIS Quarterly. 2000, 24(1), 81-113.

[17] Gartlan, J.; Shanks, G. The Alignment of Business and Information Technology Strategy in Australia. Australasian Journal of Information Systems. 2007, 14(2), 113-133.

[18] Beveridge, C. Guidelines for IT management: Aligning IT with Business Strategy. The National Computing Center Limited (NCC), UK, Guideline 273. n.d.

[19] Chan, Y. Why Haven't we Mastered Alignment? The Importance of the Informal Organization Structure. MIS Quarterly Executive. 2002, 1(2).

[20] Almajali, D.; Dahalin, Z. Factors influencing IT-Business Strategic Alignment and Sustainable Competitive Advantage: A Structural Equation Modelling Approach. 2011, Retrievedfrom: http://www.ibimapublishing.com/journals/CIBIMA/cibima.html.

[21] Nickerson, R.; Jamie, E.; Ho, L. An Exploratory Study of Strategic Alignment and Global Information System Implementation Success in Fortune 500 Companies. Ninth Americas Conference on Information System. 2003, 1683-1688.

[22] Avison, D.; Jones, J.; PowelL, P.; Wilson, D. Using and validating the strategic alignment model. The Journal of Strategic Information Systems. 2004, 13 (3), 223-246.

[23] Bleistein, J. Strategic Alignment in Requirements Analysis for Organizational IT: An Integrated Approach. Paper presented at Asia Pacific Software Engineering Conference, Busan, Korea. 2004.

[24] Das, S.; Zahra, S.; Warkentin, M. Integrating the content and process of strategic MIS planning with competitive strategy. Decision Sciences Journal. 1991, 22(5), 953-984.

[25] Basir, H.; NorzaidI, M. The Effect of Strategic Alignment on Strategic Information System Planning (SISP) Success: An Exploratory Study in Public Universities in Malaysia. International Journal of Scientific Research in Education. 2009, 2 (2), 76-87.

[26] Newkirk, H.; Lederer, A. Incremental and comprehensive strategic information systems planning, in an uncertain environment. IEEE Transactions on Engineering Management. 2006, 53(3), 380-394. 
[27] Chung, S.; Rainer, R.; Lewis, B. The Impact of Information Technology Infrastructure Flexibility on Strategic Alignment and Applications Implementation. Communications of the Association for Information Systems. 2003, 11(1), 191-206.

[28] Teo, T.; King, W. Integration between business planning and information systems planning: An evolutionary-contingency perspective. Journal of Management Information Systems. 1997, 14(1), 185-214.

[29] Simonsen, J. How do we take care of strategic alignment? Constructing a design approach, Scandinavian. Journal of Information Systems. 1999, 11(1), 1-12.

[30] Lederer, A.; Sethi, V. Key Prescriptions for Strategic Information Systems Planning. Journal of Management Information Systems. 1996, 13(1), 35-62.

[31] Bowman, B.; Davis, G.; Wetherbe, J. Three stage model of MIS planning. Information \& Management Journal. 1983, 6 (3), 11-25.

[32] Koi-Akrofi, G.Y. (2017). Justification for IT investments: Evaluation methods, frameworks, and models. Texila International Journal of Management. TIJ, TAU, Vol. 3, issue 2.

[33] Schubert, P.; Williams, S. P. A Framework for Identifying and Understanding Enterprise Systems Benefits. Business Process Management Journal. 2011, Vol. 17, No.5, pp. 808-828

[34] Drost, R.; Harmsen, F.; Brinkkemper, S.; Versendaal, J.M. Utrecht University. Department of Information and Computing Sciences. 2011.

[35] Radhakrishnan, A., Zu, X.; Grover, V. A process-oriented perspective on differential business value creation by information technology: An empirical investigation. The international journal of Management Science, Omega, ELSEVIER. 2008, Vol. 36, pp. 1105-1125.

[36] Hočevar, B.; Jaklič, J. Assessing benefits of business intelligence systems - a case study. Management. 2010, Vol. 15, no.1, pp. 87-119.

[37] Carver, A.; Ritacco, M. The Business Value of Business Intelligence. A Framework for Measuring the Benefits of Business Intelligence. Business Objects. 2006.

[38] Ashurst, C.; Doherty, N.F.; Peppard, J. Improving the impact of IT development projects: The Benefits Realization Capability Model. European Journal of Information Systems. 2008, 17 (4), pp. 352-370.

[39] Lin, C.; Pervan, G. The practice of IS/IT benefits management in large Australian organizations. Information \& Management. 2003, 41 (1), 31-44.

[40] Markus, M.L. Technochange management: using IT to drive organizational change. Journal of Information Technology. 2004, 19 (1), 4-20.

[41] Peppard J.; Ward J. Unlocking sustained business value from IT investments. California Management Review, fall. 2005, 52-69.

[42] Hughes, A.; Scott Morton, M.S. The transforming power of complementary assets. MIT Sloan Management Review, summer. 2006, 50-58.

[43] Ward, J.; Daniel, E. Benefits Management: Delivering Value from IS \& IT Investments. Wiley, Chichester. 2006.

[44] Mithas, S.; Ramasubbu, N.; Sambamurthy, V. How information management capability influences firm performance. MIS Quarterly. 2011, Vol. 35 No. 1 pp. 237-256.

[45] Castel, A. G.; Gorriz, C. G. How to measure information and communication technology performance: a literature review. Issues in Information Systems, 2007, Volume 8, No. 2.

[46] Sakar, p.; Widestadh, C. Benefits management - How to realize the benefits of IS/IT investments. Department of Informatics, IT University of Göteborg, Göteborg University and Chalmers University of Technology. 2005.

[47] Dale Stoel, M. D.; Muhanna, W. A. IT Capabilities and Firm Performance: A Contingency Analysis of the Role of Industry and IT Capability type. Information \& Management, ScienceDirect, Elsevier. 2009, Volume 46, Issue 3, Pages 181-189

[48] Karlsson, E.; Stypsanelli, M. IT investment decision making - the value of intangible benefits. Department of Informatics, Lund University, 2012.

[49] Schryen, G. Revisiting IS business value research: what we already know, what we still need to know, and how we can get there. European Journal of Information Systems. 2013, 22, 139-169.

[50] Gregor, S.; Martin, M.; Fernandez, W.; Stern, S.; Vitale, M. The transformational dimension in the realization of business value from information technology. Journal of Strategic Information Systems, ScienceDirect, Elsevier. 2006, 15, 249-270 
[51] Ahmad, F.; Arshad, N. H. Value Delivery of Information Technology Investment: A Conceptual Framework. International Journal of Computer Theory and Engineering. 2014, Vol. 6, No. 2, PP. 150-154.

[52] Hitt, L.M.; Brynjolfsson, E. Productivity, business profitability, and consumer surplus: Three different measures of information technology value. MIS Quarterly. 1996, 20 (2), 121-142.

[53] Sircar, S.; Turnbow, J. L.; Bordoloi, B. A Framework for Assessing the Relationship between Information Technology Investments and Firm Performance. Journal of Management Information systems. 2000, 16(4), pp.69-97.

[54] Beccalli, E. Does IT investment improve bank performance? Evidence from Europe. Wolpertinger 2005 Meeting, the European Accounting Association Conference 2005, Research Colloquia at UniversituaCattolica del SacroCuore (Milan).2005.

[55] Stratopoulos T.; Dehning B. Does successful investment in information technology solve the productivity paradox? Inf. Manage. 2000, 38(2):103- 17.

[56] Brynjolfsson, E. The Productivity Paradox of Information Technology. Communications of the ACM. 1993, 36(12), pp.67-77.

[57] Brynjolfsson, E.; Hitt, L. Information Technology as a Factor of Production: The Role of Differences among Firms. Economics of Innovation and New Technology (Special No. on Information Technology and Productivity Paradox). 1995, 3(4), pp.183-200.

[58] Brynjolfsson, E.; Hitt, L. Paradox lost? Firm-level Evidence on the Return to Information Systems. Management Science. 1996, 42(4), pp.541-558.

[59] Brynjolfsson, E.; Hitt, L. M. Beyond Computation: Information Technology, Organizational Transformation, and Business Performance. Journal of Economic Perspectives. 2000, 14, no. 4.

[60] Bharadwaj, A. S.; Konsynski, B. R. Capturing the intangibles, Information Week. 1997, Issue 649, 71-74.

[61] Richardson, V.J.; Subramani, M.; Zmud, R.W. Benefiting from information technology investments: The role of IT conversion capability. Mimeo. 2003.

[62] Davenport T. Process innovation. Boston (MA): Harvard Business School Press. 1993.

[63] Hammer, M.; Champy, J. Reengineering the corporation: A manifesto for business revolution. New York, NY: McGraw-Hill. 1993.

[64] Barua, A.; Kriebel, C. H.; Mulhopadhyay, T. Information Technologies and Business Value: An Analytic and Empirical Investigation. Information Systems Research. 1995, 6(1), pp.3-23.

[65] Bresnahan, T. F. Measuring the spillovers from technical advance: Mainframe computers in financial services. American Economic Review. 1986, 76(4):742-755.

[66] Brynjolfsson, E. The contribution of information technology to consumer welfare. Information Systems Research. 1996, 7(3): 281-300.

[67] Brynjolfsson, E. VII Pillars of IT Productivity. Optimize. 2003.

[68] Doherty, M. Mapping ROI. American City \& County. 2005, Vol. 120, No. 2, pp. 32 - 34.

\section{AUTHOR}

Godfred Yaw Koi-Akrofi is a senior lecturer and HOD for the Information Technology Studies Department of the University of Professional Studies, Accra in Ghana. He has a Ph.D. in Management- Information Systems Management (ISM) from Universidad Central de Nicaragua (UCN), MBA in Management Information Systems (MIS) from University of Ghana Business School (UGBS), University of Ghana, Accra, Ghana, and Bachelor of Science (B.Sc.) in Electrical/Electronic Engineering, Kwame Nkrumah University of Science and Technology (KNUST), Kumasi, Ghana. He has

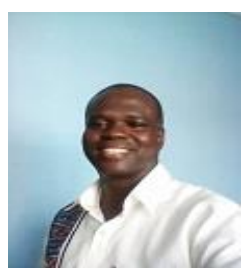
worked with multinationals such as British Telecom, AT \& T, MCI Communications Corp., Sprint Corporation, Verizon Communications, Deutsche Telekom, KPN, Orange, Telenor ASA, and so on as a Telecom engineer/Manager and Interconnect (Technical, Sales and Accounting) Manager with Ghana Telecom/Vodafone Ghana/Huawei Technologies for over 10 years. He has Twelve years of experience as a lecturer in Tertiary education. He has 19 peer-reviewed journal articles, three books, and three conference papers. Areas of Research are in IT/IS Management, Telecommunications, MIS and the organization, Organizational Behaviour, and Management, Business Organizational Dynamics, Post-Merger/Acquisition Dynamics in the Telecoms and IT sectors, Quality Management, IS/IT/Business Strategy, IT/IS Project Management/ IT Design and Systems Thinking, IT investments and organizational performance, Complementary assets and value creation beyond IT investments. 